\title{
Influence of Various Protected Structures on Physiological Response of Tomato Cultivars (Solanum lycopersicum L.)
}

\author{
M. Sasirekha*, B.B. Channappagoudar, S.M. Mantur and S.K. Gali \\ Department of Crop Physiology, College of Agriculture, University of Agricultural Sciences, \\ Dharwad-580 005, Karnataka, India \\ *Corresponding author
}

\begin{tabular}{l} 
K e y w o r d s \\
$\begin{array}{l}\text { Light transmission } \\
\text { ratio, Photosynthetic } \\
\text { rate, Polyhouse, Shade } \\
\text { house, Tomato }\end{array}$ \\
Article Info \\
$\begin{array}{l}\text { Accepted: } \\
\text { 06 August } 2018 \\
\text { Available Online: } \\
\text { 10 September } 2018\end{array}$ \\
\hline
\end{tabular}

A B S T R A C T

A field experiment was conducted at Hi-Tech Horticultural Unit, Main Agricultural Research Station, University of Agricultural Sciences, Dharwad during rabi, 2015-16 to study physiological responses of tomato cultivars viz., STH-801, STH-510 and STH-39to three different protected conditions viz., polyhouse, shade house with 35 and 50 per cent shade net. Among the different growing conditions, polyhouse recorded significantly lowest plant height $(80.00,114.27$ and $172.27 \mathrm{~cm}$ at 45 and 75 DAT and harvest, respectively), higher light transmission ratio $(36.54,22.92$ and $19.17 \% 45$ and 75 DAT and harvest, respectively), canopy temperature $\left(27.85,35.16\right.$ and $37.85{ }^{\circ} \mathrm{Cat} 45$ and 75 DAT and harvest, respectively), specific leaf weight, photosynthetic rate $(20.59,17.48$ and $15.67 \mu \mathrm{mol} \mathrm{CO} \mathrm{Cm}_{2}^{-2} \mathrm{~s}^{-1}$ at 45 and $75 \mathrm{DAT}$ and harvest, respectively) which resulted in higher yield (2.87 kg plant ${ }^{-1}$ and $\left.97.02 \mathrm{t} \mathrm{ha}^{-1}\right)$ as compared to shade house with 35 and 50 per cent shade net. The tomato hybrid, STH-801 was found to have significantly highest canopy temperature, specific leaf weight $\left(7.97,9.22\right.$ and $9.29 \mathrm{mg} \mathrm{cm}^{-2}$ at 45 and $75 \mathrm{DAT}$ and harvest, respectively), photosynthetic rate, yield $\left(2.43 \mathrm{~kg} \mathrm{p}^{-1}\right.$ and $\left.82.17 \mathrm{t} \mathrm{ha}^{-1}\right)$ as compared to STH-510 and STH-39. The tomato hybrid, STH-801 showed optimum height, higher light transmission ratio, canopy temperature, specific leaf weight, photosynthetic rate and yield under polyhouse condition.

\section{Introduction}

Tomato is one of most popular and nutritious fruit vegetables, widely grown around the world. Total area under tomato crop in India was 0.88 million ha with the production of 18.74 Mt with productivity of $21.2 \mathrm{Mt} \mathrm{ha}^{-1}$ (Anon., 2014). Rapid surge in the demand for vegetables that contributed to their high prices necessitates technological interventions that can boost their production and ensure yearround supply. One such technology with considerable potential is "protected cultivation". The greenhouse protects the plants from adverse climatic conditions and provides an appropriate amount of light, temperature, humidity, carbon dioxide etc., to achieve optimum yield with excellent quality.

Tomato is the main vegetable crop grown under protected cultivation round the year. Partial control of the microclimatic conditions which have a major influence on plant growth characteristics can be achieved in glasshouses 
or poly-greenhouses. The shade house protects the crop from adverse climatic conditions like high light intensity and temperature. The shading is effective in reducing the temperature there by creating a better microclimate inside the shade house for production of higher yield and quality fruit (Tiwari et al., 2002). Changes in greenhouse microclimates with have significant effects on growth, development and productivity of crops. There is a need to understand the crop growth response to various environmental factors prevailing under different protected conditions. With this backdrop, the present study was carried out to analyse the physiological responses of tomato cultivars grown under different protected conditions.

\section{Materials and Methods}

The experiment was carried out at $\mathrm{Hi}-\mathrm{Tech}$ Horticulture Unit, Saidapur Farm, MARS, University of Agricultural Sciences, Dharwad during December 2015 to March 2016. The treatments include three different growing conditions viz.,polyhouse $\left(\mathrm{C}_{1}\right)$, shade house with 35 per cent shade net $\left(\mathrm{C}_{2}\right)$ and shade house with 50 per cent shade net $\left(\mathrm{C}_{3}\right)$; and three tomato hybrids viz., STH-801, STH-510 and STH-39.The experiment was laid out in a factorial randomized block design with three replications and nine treatment combinations. The seedlings of tomato cultivars viz., STH801 $\left(\mathrm{H}_{1}\right)$, STH-510 $\left(\mathrm{H}_{2}\right)$ and STH-39 $\left(\mathrm{H}_{3}\right)$ were raised on protrays under greenhouse using sterilized coco peat media. Seedlings were planted in paired row system with zigzag manner on raised beds of $30 \mathrm{~cm}$ height, $25 \mathrm{~m}$ length and one $\mathrm{m}$ width having $50 \mathrm{~cm}$ path between the beds to enable easy cultural operations with inter and intra row spacing of $60 \mathrm{~cm}$ and $45 \mathrm{~cm}$, respectively. Irrigation and fertigation were done as per ad hoc recommendations of package of practices by UAS, Dharwad. Plants were trained along the plastic thread. Five plants were selected randomly in each replication and tagged for recording various observations on growth, physiological and yield parameters at different stages. The observations on the morphophysiological characteristics viz., plant height $(\mathrm{cm})$ and specific leaf weight $\left(\mathrm{mg} \mathrm{cm}^{-2}\right)$ were determined by using standard procedures; light transmission ratio (\%) recorded by lux meter, canopy temperature $\left({ }^{\circ} \mathrm{C}\right)$ by infra-red thermometer, relative chlorophyll content by SPAD meter and photosynthetic rate ( $\mu$ moles $\left.\mathrm{CO}_{2} \mathrm{~m}^{-2} \mathrm{~s}^{-1}\right)$ measured by infra-red gas analyzer (IRGA, LI-COR Photosystem) were recorded at various crop growth stages like 45, 75 DAT and harvest and yield was calculated on cumulative basis.

\section{Results and Discussion}

The plant height differed significantly under different protected conditions at different growth stages (Table 1). Among the growing conditions, significantly highest plant height (93.27, 197.5 and $245.56 \mathrm{~cm}$ at 45 and 75 DAT and harvest, respectively) was recorded in shade house with 50 per cent shade net $\left(\mathrm{C}_{3}\right)$, whereas the lowest plant height $(80.00,114.27$ and $172.27 \mathrm{~cm}$ at 45 and 75 DAT and harvest, respectively) was recorded in polyhouse $\left(\mathrm{C}_{1}\right)$ at all the growth stages. The tomato hybrid STH-801 recorded highest plant height, while the lowest plant height was recorded by STH39. The environment in the polyhouse favoured the growth and development of tomato plant through increased plant height, which was comparatively less than the shade house with 50 per cent shade net. The reduced light under shade house with 50 per cent shade net might have favoured the proliferation of plant growth which might have led to the increase in the plant height as reported by Bibi et al., (2012).

Light is the most important factor affecting productivity in greenhouse tomato. The light transmission ratio of different protected 
conditions and the tomato hybrids differed significantly at different growth stages (Table 1). The significantly highest light transmission ratio was recorded in $C_{1}$, whereas, the lowest light transmission ratio was recorded in $\mathrm{C}_{3}$ at all growth stages. Among the tomato hybrids STH-801 recorded significantly highest light transmission ratio. The lowest light transmission ratio was recorded by STH-39. This might be due to the types of covering material and its light transmission properties. Under polyhouse, the diffused light conditions, light penetrates deeper into the crop resulting in a higher photosynthetic capacity. The light transmission ratio was less in shade house with 35 per cent and 50 per cent compared to polyhouse, the cladding material used in case of shade house mainly for reducing temperature. The present results can be substantiated with the findings of Dueck et al., (2012). Canopy temperature $\left({ }^{\circ} \mathrm{C}\right)$ of tomato hybrids under different protected conditions differed significantly (Table 1) and showed increasing trend. Among the growing conditions, the maximum canopy temperature was recorded in $\mathrm{C}_{1}(27.85,35.16$ and $37.85^{\circ} \mathrm{Cat} 45,75$ DAT and harvest, respectively). The tomato hybrid STH-801 recorded maximum canopy temperature $\left({ }^{\circ} \mathrm{C}\right)$ whereas the minimum temperature was recorded by STH-39. This might be due to the maximum temperature inside the polyhouse which increases the leaf temperature.

Specific leaf weight is a measure of leaf weight per unit leaf area. More specific leaf weight per unit leaf area indicates more biomass and a positive relationship with yield. There was an increasing trend in specific leaf weight during all the growth stages. Significantly higher specific leaf weight was recorded in $\mathrm{C}_{1}$ whereas the less specific leaf weight was recorded in $\mathrm{C}_{3}$. Among the tomato hybrids, maximum specific leaf weight (7.97, 9.22 and $9.29 \mathrm{mg} \mathrm{cm}^{-2}$ at 45, 75 DAT and harvest, respectively) was recorded by STH-
801 the minimum specific leaf weight was recorded by STH-510 (5.61, 6.83 and $7.13 \mathrm{mg}$ $\mathrm{cm}^{-2}$ at 45 and 75 DAT and at harvest, respectively). The interaction effect of the growing conditions and the tomato hybrids on specific leaf weight did not differ significantly. The higher specific leaf weight might be due to more thickness of leaves and also reduced leaf area, which contributed to more leaf weight (Table 2).

The relative chlorophyll content of the tomato hybrids as influenced by different protected conditions and their interactions differed significantly (Table 2). At 45 and 75 DAT and harvest, under the different growing conditions, the highest relative chlorophyll content was recorded in $\mathrm{C}_{1}$ while the lowest was recorded in $\mathrm{C}_{3}$. Among the tomato hybrids the significantly highest relative chlorophyll content was recorded by STH-801 followed by STH-39. This may be because the tomato cultivar, STH-801 was indeterminate in growth habitat which continuously grows and accumulates the photosynthates. Contrarily, there was no significant difference with respect to the interactions at initial stage of crop growth period. At harvest, the significantly highest relative chlorophyll content was recorded in $\mathrm{C}_{3}$. With respect to the interactions, highest relative chlorophyll content was recorded by STH-801 in $\mathrm{C}_{3}$ while the least was recorded by STH-39 in $\mathrm{C}_{2}$. This might be due to more chlorophyll ' $b$ ' and total chlorophyll content in $\mathrm{C}_{3}$ as reported by Singh et al., (2015).

Gas exchange measurements provide direct measure of the net rate of photosynthetic carbon assimilation. Significantly higher photosynthetic rate was recorded in $\mathrm{C}_{1}$ (20.59, 17.48 and $15.67 \mu \mathrm{mol} \mathrm{CO} \mathrm{m}^{-2} \mathrm{~s}^{-1}$ at 45 and 75 DAT and harvest, respectively) while the lowest photosynthetic rate was recorded in $\mathrm{C}_{2}$ (17.26, 15.07 and $12.04 \mu \mathrm{mol} \mathrm{CO}_{2} \mathrm{~m}^{-2} \mathrm{~s}^{-1}$, respectively at all the growth stages). 
Table.1 Plant height $(\mathrm{cm})$, light transmission ratio $(\%)$, canopy temperature $\left({ }^{\circ} \mathrm{C}\right)$ of tomato cultivars as influenced by different protected structures

\begin{tabular}{|c|c|c|c|c|c|c|c|c|c|}
\hline \multirow[t]{2}{*}{ Treatments } & \multicolumn{3}{|c|}{ Plant height } & \multicolumn{3}{|c|}{ Light transmission ratio } & \multicolumn{3}{|c|}{ Canopy temperature } \\
\hline & 45 DAT & $75 \mathrm{DAT}$ & At Harvest & $45 \mathrm{DAT}$ & $75 \mathrm{DAT}$ & At Harvest & $45 \mathrm{DAT}$ & $75 \mathrm{DAT}$ & At Harvest \\
\hline \multicolumn{10}{|l|}{ Growing conditions (C) } \\
\hline $\mathrm{C}_{1}$ : Polyhouse & $80.00^{b}$ & $140.78^{b}$ & $172.27^{\mathrm{b}}$ & $36.54^{\mathrm{a}}$ & $22.92^{\mathrm{a}}$ & $19.17^{\mathrm{a}}$ & $27.85^{\mathrm{a}}$ & $35.16^{\mathrm{a}}$ & $37.85^{\mathrm{a}}$ \\
\hline$C_{3}$ : Shade house with 50 per cent shade net & $93.27^{\mathrm{a}}$ & $197.5^{\mathrm{a}}$ & $245.56^{\mathrm{a}}$ & $20.61^{\mathrm{b}}$ & $15.27^{\mathrm{b}}$ & $7.57^{\mathrm{c}}$ & $24.28^{\mathrm{b}}$ & $26.56^{\mathrm{b}}$ & $30.11^{\mathrm{b}}$ \\
\hline S.Em \pm & 2.16 & 4.77 & 3.13 & 1.49 & 0.94 & 0.76 & 0.22 & 0.31 & 0.32 \\
\hline LSD@5\% & 6.46 & 14.29 & 9.39 & 4.48 & 2.81 & 2.28 & 0.66 & 0.93 & 0.96 \\
\hline $\mathrm{H}_{1}:$ STH-801 & $97.84^{\mathrm{a}}$ & $219.74^{\mathrm{a}}$ & $258.7^{\mathrm{a}}$ & 29.26 & 20.49 & $15.66^{\mathrm{a}}$ & $26.97^{\mathrm{a}}$ & $31.42^{\mathrm{a}}$ & $34.88^{\mathrm{a}}$ \\
\hline $\mathrm{H}_{2}:$ STH-510 & $82.91^{\mathrm{b}}$ & $169.64^{b}$ & $203.0^{\mathrm{b}}$ & 27.49 & 19.48 & $13.65^{\mathrm{ab}}$ & $25.56^{\mathrm{b}}$ & $29.82^{\mathrm{a}}$ & $34.26^{\mathrm{ab}}$ \\
\hline $\mathrm{H}_{3}:$ STH-39 & $72.86^{\mathrm{b}}$ & $114.27^{\mathrm{c}}$ & $141.8^{\mathrm{c}}$ & 25.79 & 16.56 & $11.20^{\mathrm{b}}$ & $24.88^{b}$ & $28.04^{b}$ & $33.09^{b}$ \\
\hline S.Em \pm & 2.16 & 4.77 & 3.13 & 1.49 & 0.94 & 0.76 & 0.22 & 0.31 & 0.32 \\
\hline LSD@ $5 \%$ & 6.46 & 14.29 & 9.39 & NS & NS & 2.28 & 0.66 & 0.93 & 0.96 \\
\hline \multicolumn{10}{|l|}{ Interactions $(\mathrm{CxH})$} \\
\hline $\mathrm{C}_{1} \mathrm{H}_{1}$ & $103.87^{\mathrm{a}}$ & $177.07^{\mathrm{cd}}$ & $223.87^{c}$ & 38.63 & 22.67 & $23.20^{\mathrm{a}}$ & $29.88^{\mathrm{a}}$ & $38.16^{\mathrm{a}}$ & 38.69 \\
\hline $\mathrm{C}_{1} \mathrm{H}_{2}$ & $67.93^{\mathrm{e}}$ & $152.33^{\mathrm{de}}$ & $175.53^{\mathrm{d}}$ & 35.7 & 24.21 & $20.07^{\mathrm{ab}}$ & $26.98^{b}$ & $34.23^{b}$ & 37.92 \\
\hline $\mathrm{C}_{2} \mathrm{H}_{1}$ & $86.00^{b c}$ & $216.73^{b}$ & $236.60^{b c}$ & 27.13 & 20.61 & $16.26^{\mathrm{bc}}$ & $25.64^{\mathrm{cd}}$ & $28.65^{c}$ & 35.29 \\
\hline $\mathrm{C}_{2} \mathrm{H}_{2}$ & $84.93^{b c}$ & $172.33^{\mathrm{cd}}$ & $190.20^{\mathrm{d}}$ & 26.31 & 19.35 & $12.95^{\mathrm{c}}$ & $25.35^{\mathrm{de}}$ & $28.02^{c}$ & 34.67 \\
\hline $\mathrm{C}_{2} \mathrm{H}_{3}$ & $70.10^{\mathrm{de}}$ & $107.07^{\mathrm{f}}$ & $130.30^{\mathrm{e}}$ & 22.74 & 15.07 & $12.07^{\mathrm{c}}$ & $24.86^{\mathrm{de}}$ & $26.00^{\mathrm{de}}$ & 32.83 \\
\hline $\mathrm{C}_{3} \mathrm{H}_{1}$ & $103.67^{\mathrm{a}}$ & $265.43^{\mathrm{a}}$ & $315.67^{\mathrm{a}}$ & 22 & 18.2 & $7.52^{\mathrm{d}}$ & $25.39^{\mathrm{de}}$ & $27.47^{\mathrm{cd}}$ & 30.65 \\
\hline $\mathrm{C}_{3} \mathrm{H}_{2}$ & $95.87^{\mathrm{ab}}$ & $184.27^{c}$ & $243.33^{b}$ & 20.47 & 14.87 & $7.93^{d}$ & $24.35^{\mathrm{e}}$ & $27.20^{\mathrm{cd}}$ & 30.19 \\
\hline $\mathrm{C}_{3} \mathrm{H}_{3}$ & $80.27^{\mathrm{cd}}$ & $142.80^{\mathrm{e}}$ & $177.67^{\mathrm{d}}$ & 19.35 & 12.74 & $7.27^{d}$ & $23.10^{\mathrm{f}}$ & $25.02^{\mathrm{e}}$ & 29.51 \\
\hline S.Em \pm & 3.73 & 8.26 & 5.42 & 2.59 & 1.62 & 1.31 & 0.38 & 0.54 & 0.55 \\
\hline LSD@5\% & 11.2 & 24.75 & 16.26 & NS & NS & 3.94 & 1.14 & 1.6 & NS \\
\hline
\end{tabular}

Note: Values in the column followed by the same letters do not differ significantly by DMRT, NS - Non-significant, DAT - Days after transplanting 
Table.2 Specific leaf weight $\left(\mathrm{mg} \mathrm{cm}^{-2}\right)$ and relative chlorophyll content (SPAD), photosynthetic rate $\left(\mu \mathrm{mol} \mathrm{CO}_{2} \mathrm{~m}^{-2} \mathrm{~s}^{-1}\right)$ and yield of tomato cultivars as influenced by different protected structures

\begin{tabular}{|c|c|c|c|c|c|c|c|c|c|c|c|}
\hline \multirow[t]{2}{*}{ Treatments } & \multicolumn{3}{|c|}{ Specific leaf weight } & \multicolumn{3}{|c|}{ Relative chlorophyll content } & \multicolumn{3}{|c|}{ Photosynthetic rate } & \multicolumn{2}{|c|}{ Yield } \\
\hline & $45 \mathrm{DAT}$ & 75 DAT & $\begin{array}{c}\text { At } \\
\text { Harvest }\end{array}$ & $45 \mathrm{DAT}$ & 75 DAT & $\begin{array}{c}\text { At } \\
\text { Harvest }\end{array}$ & $45 \mathrm{DAT}$ & 75 DAT & At harvest & $\left(\mathrm{kg}_{\text {plant }}{ }^{-1}\right)$ & $\left(\mathrm{t} \mathrm{ha}^{-1}\right)$ \\
\hline \multicolumn{12}{|l|}{ Growing conditions $(\mathrm{C})$} \\
\hline $\mathrm{C}_{1}$ : Polyhouse & $8.15^{\mathrm{a}}$ & $8.76^{\mathrm{a}}$ & $8.96^{\mathrm{a}}$ & $56.20^{\mathrm{a}}$ & $53.32^{\mathrm{a}}$ & $43.48^{\mathrm{a}}$ & $20.59^{\mathrm{a}}$ & $17.48^{\mathrm{a}}$ & $15.67^{\mathrm{a}}$ & $2.87^{\mathrm{a}}$ & $97.02^{\mathrm{a}}$ \\
\hline $\begin{array}{l}\mathrm{C}_{2} \text { : Shade house with } \\
35 \text { per cent shade net }\end{array}$ & $6.55^{\mathrm{b}}$ & $7.50^{\mathrm{b}}$ & $7.91^{\mathrm{b}}$ & $52.60^{\mathrm{b}}$ & $50.43^{\mathrm{b}}$ & $34.84^{\mathrm{b}}$ & $17.26^{\mathrm{b}}$ & $15.07^{\mathrm{b}}$ & $12.04^{\mathrm{b}}$ & $2.19^{\mathrm{b}}$ & $74.13^{b}$ \\
\hline $\begin{array}{l}\mathrm{C}_{3} \text { : Shade house with } \\
50 \text { per cent shade net }\end{array}$ & $5.50^{\mathrm{c}}$ & $7.66^{\mathrm{b}}$ & $7.77^{\mathrm{b}}$ & $49.49^{c}$ & $45.46^{\mathrm{c}}$ & $44.27^{\mathrm{a}}$ & $18.97^{\mathrm{ab}}$ & $16.54^{\mathrm{ab}}$ & $14.00^{\mathrm{ab}}$ & $1.81^{\mathrm{b}}$ & $61.05^{\mathrm{b}}$ \\
\hline S.Em \pm & 0.13 & 0.19 & 0.16 & 0.53 & 0.49 & 0.5 & 0.34 & 0.38 & 0.53 & 0.12 & 4.01 \\
\hline LSD@ $5 \%$ & 0.39 & 0.56 & 0.49 & 1.58 & 1.47 & 1.49 & 1.01 & 1.15 & 1.59 & 0.36 & 12.02 \\
\hline \multicolumn{12}{|l|}{ Hybrids (H) } \\
\hline $\mathrm{H}_{1}$ : STH-801 & $7.97^{\mathrm{a}}$ & $9.22^{\mathrm{a}}$ & $9.29^{\mathrm{a}}$ & $54.35^{\mathrm{a}}$ & 50.85 & $42.96^{\mathrm{a}}$ & 19.62 & 17.05 & 15.34 & $2.43^{\mathrm{a}}$ & $82.17^{\mathrm{a}}$ \\
\hline $\mathrm{H}_{2}$ : STH-510 & $5.61^{\mathrm{c}}$ & $6.83^{c}$ & $7.13^{c}$ & $51.05^{\mathrm{b}}$ & 48.87 & $39.64^{b}$ & 19.09 & 16.53 & 13.38 & $2.03^{\mathrm{b}}$ & $68.44^{\mathrm{b}}$ \\
\hline $\mathrm{H}_{3}:$ STH-39 & $6.61^{\mathrm{b}}$ & $7.87^{\mathrm{b}}$ & $8.21^{\mathrm{b}}$ & $52.89^{\mathrm{ab}}$ & 49.48 & $39.99^{b}$ & 18.1 & 15.5 & 12.98 & $2.41^{\mathrm{a}}$ & $81.58^{\mathrm{a}}$ \\
\hline S.Em \pm & 0.13 & 0.19 & 0.16 & 0.53 & 0.49 & 0.5 & 0.34 & 0.38 & 0.53 & 0.12 & 4.01 \\
\hline LSD@ 5 \% & 0.39 & 0.56 & 0.49 & 2.74 & NS & 1.49 & NS & NS & NS & 0.36 & 0.36 \\
\hline \multicolumn{12}{|l|}{ Interactions (CxH) } \\
\hline $\mathrm{C}_{1} \mathrm{H}_{1}$ & $8.78^{a}$ & 9.62 & 9.78 & 58.33 & 54.37 & $45.01^{\mathrm{ab}}$ & $21.78^{\mathrm{a}}$ & $18.81^{\mathrm{a}}$ & $16.73^{\mathrm{a}}$ & $3.49^{\mathrm{a}}$ & $117.87^{\mathrm{a}}$ \\
\hline $\mathrm{C}_{1} \mathrm{H}_{2}$ & $7.47^{\mathrm{bc}}$ & 7.8 & 7.81 & 53.85 & 52.47 & $42.08^{\mathrm{cd}}$ & $19.84^{\mathrm{b}}$ & $17.62^{\mathrm{ab}}$ & $16.72^{\mathrm{a}}$ & $2.46^{\mathrm{bc}}$ & $83.24^{\mathrm{bc}}$ \\
\hline $\mathrm{C}_{1} \mathrm{H}_{3}$ & $8.20^{\mathrm{a}}$ & 8.86 & 9.28 & 56.41 & 53.12 & $43.33^{b-d}$ & $20.15^{\mathrm{ab}}$ & $16.01^{b-d}$ & $13.55^{\mathrm{bc}}$ & $2.66^{\mathrm{b}}$ & $89.95^{\mathrm{b}}$ \\
\hline $\mathrm{C}_{2} \mathrm{H}_{1}$ & $8.15^{\mathrm{ab}}$ & 8.87 & 8.96 & 53.81 & 51.37 & $37.34^{\mathrm{e}}$ & $16.86^{\mathrm{de}}$ & $16.01^{\mathrm{b}-\mathrm{d}}$ & $11.70^{\text {cd }}$ & $2.41^{\mathrm{bc}}$ & $81.36^{\mathrm{bc}}$ \\
\hline $\mathrm{C}_{2} \mathrm{H}_{2}$ & $5.24^{\mathrm{e}}$ & 6.35 & 6.99 & 51.03 & 49.67 & $32.24^{\mathrm{f}}$ & $18.51^{\mathrm{b}-\mathrm{d}}$ & $15.16^{\text {cd }}$ & $14.39^{\mathrm{a}-\mathrm{c}}$ & $1.67^{\mathrm{de}}$ & $56.53^{\mathrm{de}}$ \\
\hline $\mathrm{C}_{2} \mathrm{H}_{3}$ & $6.25^{\mathrm{d}}$ & 7.29 & 7.77 & 52.97 & 50.24 & $34.94^{\mathrm{e}}$ & $16.40^{\mathrm{e}}$ & $14.064^{\mathrm{d}}$ & $10.03^{\mathrm{d}}$ & $2.50^{\mathrm{bc}}$ & $84.50^{\mathrm{bc}}$ \\
\hline $\mathrm{C}_{3} \mathrm{H}_{1}$ & $6.99^{c}$ & 9.16 & 9.13 & 50.91 & 46.82 & $46.54^{a}$ & $20.22^{\mathrm{ab}}$ & $16.34^{\mathrm{bc}}$ & $11.73^{\mathrm{cd}}$ & $1.40^{\mathrm{e}}$ & $47.29^{e}$ \\
\hline $\mathrm{C}_{3} \mathrm{H}_{2}$ & $4.12^{\mathrm{f}}$ & 6.35 & 6.58 & 48.27 & 44.48 & $44.59^{\mathrm{a}-\mathrm{c}}$ & $18.93^{\mathrm{bc}}$ & $17.92^{\mathrm{ab}}$ & $14.89^{\mathrm{ab}}$ & $1.94^{\mathrm{c}-\mathrm{e}}$ & $65.56^{c-e}$ \\
\hline $\mathrm{C}_{3} \mathrm{H}_{3}$ & $5.38^{\mathrm{e}}$ & 7.46 & 7.58 & 49.3 & 45.09 & $41.69^{\mathrm{d}}$ & $17.75^{\mathrm{c}-\mathrm{e}}$ & $15.34^{\text {cd }}$ & $15.36^{\mathrm{ab}}$ & $2.08^{\mathrm{b}-\mathrm{d}}$ & $70.31^{\mathrm{b}-\mathrm{d}}$ \\
\hline S.Em \pm & 0.23 & 0.33 & 0.28 & 0.91 & 0.85 & 0.86 & 0.58 & 0.67 & 0.92 & 0.21 & 6.95 \\
\hline LSD@ $5 \%$ & 0.68 & NS & NS & NS & NS & 2.58 & 1.75 & 1.99 & 2.76 & 0.62 & 20.83 \\
\hline
\end{tabular}


Among the interactions, the highest photosynthetic rate was recorded by STH-801 in $\mathrm{C}_{1}$ whereas the lowest photosynthetic rate was recorded by STH-39 in $\mathrm{C}_{2}$ at all growth stages (Table 2). This might be due to higher temperature prevailed under $\mathrm{C}_{1}$ which led the plants to cool themselves by the process of transpiration and accumulation of $\mathrm{CO}_{2}$ inside the structure.

The plants utilize this accumulated $\mathrm{CO}_{2}$ for photosynthesis. Also the diffuse light under polyhouse penetrates deep into the crop canopy which contributes higher photosynthetic capacity. In case of $\mathrm{C}_{3}$, even though the light transmission was less, the higher chlorophyll content contributed higher photosynthetic capacity. The photosynthetic rate decreases as the age of the crop.

Significantly highest yield was recorded in $\mathrm{C}_{1}$ (2.87 kg plant ${ }^{-1}$ and $97.02 \mathrm{t} \mathrm{ha}^{-1}$ ) followed by $\mathrm{C}_{2}\left(2.19 \mathrm{~kg}\right.$ plant ${ }^{-1}$ and $\left.74.13 \mathrm{t} \mathrm{ha}^{-1}\right)$. Yield of the tomato hybrids varied significantly (Table 2). A significantly higher yield was recorded by STH-801 (2.43 kg p ${ }^{-1}$ and $\left.82.17 \mathrm{t} \mathrm{ha}^{-1}\right)$ followed by STH-39 (2.41 kg plant ${ }^{-1}$ and $81.58 \mathrm{t} \mathrm{ha}^{-1}$ ).

Among the interactions, the significantly highest yield was recorded by STH-801 in $\mathrm{C}_{1}$ (3.49 kg plant ${ }^{-1}$ and $117.87 \mathrm{t} \mathrm{ha}^{-1}$ ) whereas the lowest yield was recorded by STH-801 in $\mathrm{C}_{3}$ $\left(1.40 \mathrm{~kg}\right.$ plant $^{-1}$ and $\left.47.29 \mathrm{t} \mathrm{ha}^{-1}\right)$. The microclimate that prevailed inside the polyhouse favoured the plant throughout the crop growth period. These results could be substantiated with the findings of Mantur et al., (2014) who observed significantly higher fruit yield per plant in cherry tomato. Similar findings were reported by Biradar et al., (2015) who reported higher productivity of capsicum under polyhouse.

In conclusion, the morpho-physiological parameters viz., plant height, light transmission ratio, canopy temperature, chlorophyll content (SPAD), photosynthetic rate and yield were significantly differed under different growing conditions. Among the tomato hybrids, STH-801 was found to be more superior both in terms of morphophysiological and yield under polyhouse condition, followed by shade house with 35 per cent shade net and shade house with 50 per cent shade net. The light transmission ratio, canopy temperature, specific leaf weight, chlorophyll content (SPAD), photosynthetic rate were positively correlated with tomato yield.

\section{References}

Anonymous, 2014, Rep.(2014).National Horticulture Board, Indian Horticulture Database, Ministry of Agriculture, New Delhi, India, pp. 4-254.

Bibi, B., Sajid, M., Rab, A., Shah, S. T., Ali, N., Jan, I., Haq, I., Wahid, F. I., Haleema, B. and Ali, I., 2012.Effect of partial shade on growth and yield of tomato cultivars. Gl. J. Biol. Agric. Health Sci., 1(1): 22-26.

Biradar, M. S., Patil, C. R. and Mantur, S. M., 2015. Productivity and quality of colour capsicum as influenced by protected environment, planting geometry and pruning of stems. Environ. Ecol., 33(1B): 549-553.

Dueck, T., Janse, J., Kempkes, F. and Eveleens, B., 2012. Influence of diffuse glass on the growth and production of tomato. ActaHortic., 956: 75-82.

Mantur, S. M., Biradhar, M. S., Patil, A. A. and Mannikeri, I. M., 2014. Effect of spacing on cherry tomato varieties grown under shade house. Karnataka J. Agric. Sci., 27(2): 199-201.

Singh, J., Nangare, D. D., Meena, V.S., Bhushan, B., Bhatnagar, P.R. and Sabir, N., 2015. Growth, quality and pest infestation in tomato under protected 
cultivation in semi-arid region of Punjab. Indian J. Hortic., 72(4): 518522.
Tiwari, R. N., Mishra, M., Choudhary, B. and Palni, S.K., 2002. Tomato. In: Vegetable crops, (1): 49-51.

\section{How to cite this article:}

Sasirekha, M., B.B. Channappagoudar, S.M. Mantur and Gali, S.K. 2018. Influence of Various Protected Structures on Physiological Response of Tomato Cultivars (Solanum lycopersicum L.). Int.J.Curr.Microbiol.App.Sci. 7(09): 487-493. doi: https://doi.org/10.20546/ijcmas.2018.709.058 